the Scottish red grouse. The Flanders dunes have a very interesting flora, in many ways like that of the dunes of South Wales, western Lancashire or Norfolk. In the wet dunes and pools grow grass of Parnassus, round-leaved wintergreen, purple loosestrife, hemlock, storksbill, and on the dry ones, toadflax, bird's-foot trefoil, creeping willow, pink centaury, squinancy wort, burnet rose, Chinese box thorn, evening primrose, musk orchid, marsh helleborine, etc. The alien evening primrose on the Dutch dumes is associated with the important researches of de Vries and the doubling of chromosomes in Enothera Lamarckiana. The famous Flanders poppies, increased by the calcareous nature of the soil following the bombardment of buildings in the War of 1914-18, had declined in numbers in recent years as the soil had returned to more normal type.

\section{The Food Industry in War-time}

IN a lecture at the Royal Institution on May 21 in the series "The Nation's Larder", Dr. L. H. Lampitt, director and chief chemist of Messrs. J. Lyons and Co., Ltd., discussed "The Manufacture, Preservation and Distribution of Food". The food industry occupies a position between that of catering by households and catering of the canteen type. The economy to be effected by mass production is obvious because wastage is reduced to a minimum ; all waste products are taken and so treated that they have an economic value, labour is reduced and-a very important point-the amount of fuel consumed is considerably less. A striking example is in the baking of cakes. An ordinary gas cooker as operated by a housewife consumes approximately $10 \mathrm{cub}$. ft. of gas for each lb. of cooked weight of cakes, assuming the housewife was making 4-5 lb. of mixed cakes. In the case of a travelling oven, producing thousands of cakes an hour, the consumption of gas for each lb. of cooked weight is about $1 \frac{1}{8} \mathrm{cub}$. $\mathrm{ft}$. In the realm of the homely potato, the average housewife loses approximately 22 per cent in peeling and eyeing. In mass treatment, where peeling is carried out by mechanical means, the loss is only 11 per cent.

By far the greater proportion of the bread baked in Great Britain is produced by large mechanical bakeries, and it is not an easy task to change over plant producing loaves made from white flour to loaves made from brown flour. The utilization of edible products not previously generally used as food, or used in a different form, is comparatively simple. Examples are the Ersatz coffee of Germany made from roasted barley and the Ersatz tea made from mixed leaves and shoots. These make palatable drinks, but the effect on the body is not the same as the natural products. By complicated chemical reactions, oils of the paraffin type which are unabsorbed by the human organism can be transformed into edible fats, and this is probably being carried out in Germany to-day. The production of protein matter by the activity of specially selected strains of yeast was practised in Germany during the War of 1914-18, and factories for this purpose were in being last year.

\section{The Differential Analyser}

IN the application of mathematics to many problems both of pure and of applied science, rate of change of a quantity is often related to the magnitude of that quantity itself. This situation is expressed formally by a 'differential equation'. The differential analyser, of which the first was designed and built at the Massachusetts Institute of Technology by Dr. V. Bush and his team, is a machine for evaluating by mechanical means the solutions of differential equations, and its main applications are to problems giving rise to such equations which cannot be solved by formal methods.

Prof. D. R. Hartree, professor of theoretical physics in the University of Manchester, described the principles and applications of such a machine in his Friday evening discourse at the Royal Institution on May 17. The machine consists essentially of a number of integrating units each of which is a precision form of continuously variable gear. These units can be interconnected in various ways by shafts and gearing so as to form a translation into mechanical terms of the differential equation to be solved. There is also a number of 'input tables' from each of which information, in the form of a graph expressing the relation between two of the variables in the equation, can be supplied to the machine, and means of recording the solution of the equation either in graphical or numerical form ; there are also adding units each of which can form the sum of two terms in the equation. There are at present seven full-size machines of this kind in operation, and also in Great Britain, several small-scale ones, some built mainly of standard Mecano parts, and others workshop-built. It may be recalled that the differential analyser at Man. chester was described by Prof. Hartree in NATURE of June 8, 1935, p. 940.

\section{Summer School in Social Biology}

The Educational Advisory Board of the British Social Hygiene Council is arranging a Summer School for Teachers and Social Workers at Westminster College, Cambridge, during August 1-8. The main interest of the School will be focused upon a "SchoolLeavers' Course in Human Biology" which has recently been prepared by the Educational Advisory Board to assist in meeting the urgent problems that have arisen affecting adolescents as a result of war conditions. Various aspects of the syllabus will be presented in the form of symposia, contributed to jointly by distinguished biologists and practising school teachers. These symposia and the ensuing discussions should be of considerable value in helping participating teachers to a deeper understanding of the natural endowments of their pupils. Another section of the School will deal with some of the problems in social biology which to-day have become a matter of vital concern for the peoples of the British Empire.

Prof. J. C. Ryle, regius professor of physic in the University of Cambridge, will be president of the School, and Mr. L. J. F. Brimble will be director. 
The inaugural address will be delivered by Sir Walter Langdon-Brown, emeritus professor of physic in the University of Cambridge. The following speakers have undertaken to give lectures and take part in discussions: Prof. J. C. Drummond, scientific advisor, Ministry of Food; Dr. Leslie J. Harris, director of the Nutritional Laboratory, University of Cambridge ; Dr. Grace Calver, physician, Children's Department, Tavistock Clinic ; Mrs. C. Neville-Rolfe, past vice-president, Eugenics Society; Sir Drummond Shiels, medical secretary, British Social Hygiene Council ; Mrs. E. J. Hatfield, North London Collegiate School; Mr. R. Weatherall, Eton College ; and Miss V. D. Swaisland, British Social Hygiene Council. Further information can be obtained from the Education Officer, British Social Hygiene Council, Inc., Tavistock House South, Tavistock Square, London, W.C.1.

\section{International Relief Union}

THE origin, aims, means and future of the International Relief Union are discussed by M. Camille Gorgé in a pamphlet recently issued by the Union (Geneva: International Relief Union). M. Gorgé points out that, for good or for ill, the States of the world have become so closely welded together that they form a great family from which no one member can dissociate himself without serious inconvenience or actual hardship. Although international co-operation has at present lost most of its vitality and force, sooner or later the nations must revert to the method of collective agreements, and use the instruments or machinery already established for that purpose. The International Relief Union, which was established by the Convention of July 12, 1927, was largely the outcome of a scheme elaborated by $\mathbf{M}$. Giovanni Ciraolo to provide not only for immediate and organized relief for peoples overtaken by disasters, such as earthquakes or other catastrophes arising from natural causes, epidemics, famine, etc., but also for the scientific study of the causes of natural calamities, with the view of counteracting or limiting their effects. According to the Convention, the International Relief Union has a fourfold task : it must furnish first aid to the populations that are victims of public disasters, and co-ordinate, as occasion offers, the efforts made by other relief organizations; it must also encourage the study of preventive measures against disasters and seek to induce all peoples to render mutual international assistance.

The Convention did not come into force until December 27, 1932, and its financial resources were too limited for it to do its work freely and effectively. Special stress is laid upon the mobilization of the forces of good will against adversity beyond national frontiers, and upon encouraging scientific men to study how ta combat or even counteract future disasters. Scientific workers are urged to co-ordinate research in all its branches so that the various communities may unite their concrete efforts, based on accurate data, to minimize the damage to the human family caused by great scourges. Aviation and broadcasting have already done something to reduce the gravity of certain disasters, and fresh opportunities of foresight and defence continually arise. To assist scientific workers to explain their ideas and compare results in this field, the Union in June 1938 issued the Revue pour l'étude des calamities, replacing the Matériaux pour l'étude des calamities, previously published by M. Montandon in collaboration with the Société de Géographie de Genève. One of the first tasks of the Union in this field is to make a detailed study of the geography of natural disasters. A resolution of the first International Conference for Protection against Disasters, Paris, September 1937, recommended that the Union should consider the appointment of a Permanent International Committee for Protection against Disasters, collaborating with the Board of Scientific Documentation of the Union, and M. Gorgé briefly indicates directions in which such concerted scientific effort is required.

\section{Wood Pole Transmission Lines}

IN order to examine the incidence of risks from shocks and fire due to the use of wood-pole transmission lines, tests were undertaken of primary insulation at 19,11 and $6 \cdot 35 \mathrm{kv}$. The work is described by. G. T. Garwood in the Electrical Review of April 12. The structure on which the tests were carried out comprised a plain-sawn English oak cross-arm, 5 in. by 3 in., bolted to a red fir-pole, $32 \mathrm{ft}$. by $11 \frac{1}{4} \mathrm{in}$. in diameter at $5 \mathrm{ft}$. from the butt. The pole was sound in every way and had been creosoted. The instruments used for the tests were two electrostatic voltmeters. The resistance between the cross-arm bolt and earth was measured on frequent occasions in the period during which the test was being taken and also under varying conditions of dryness. The megger readings ranged from 200,000 ohms with the pole dry to 50,000 ohms with it wet. With the $11 \mathrm{kv}$. connexions a current of 140 micro-amperes could be obtained from below a plain earthing collar. As 15 micro-amperes may give a fatal shock to a normal man, if his heart lie in the circuit, the experiments showed that a plain earthing collar round the pole is insufficient protection. In the destruction tests, about ten minutes after the wetting of the pole smoke appeared from the cross-arm near the insulator pin. Longitudinal 'shakes' opened up in the cross-arm and showed signs of carbonizing. After about twenty minutes, smoke appeared from these shakes, the source of the smoke moving steadily towards the pole. After thirty minutes, smoke appeared from the pole top and 'tracking' with small intermittent flames at the earthing collar. Heavy smoke and flames appeared at the pole-top after seventy-five minutes and after eighty-five minutes the test was stopped, it being clear that the complete destruction of the structure was inevitable.

\section{Flavour of Bacon}

The Department of Scientific and Industrial Research has issued a report describing work carried out for the Food Investigation Board on the importance of various factors responsible for the pro- 